\title{
1. The earth is flat
}

At first there was autarkic self-sufficiency. Individuals and households produced what they planned to consume. After that there was dyadic exchange. The butcher, the brewer and the baker divided up the tasks and negotiated mutually agreeable swaps. Then there was arm's-length anonymity: minerals became metals which became tools which became cutlery which became retail. Then there was the cross-border commutation of superfluities. One country's apple was traded for another country's orange. All the players felt better off in their own estimation. The earth is flat (Friedman, 2007). Dutchman or Ethiopian, Colombian or Indonesian, we are all becoming parts one of another. Even the discontented like it that way: 'The removal of barriers to free trade and the closer integration of national economies' is 'a force that has brought so much good' (Stiglitz, 2002: ix, 4).

Interdependence and interconnectedness, trade creation and trade diversion, market-widening and market-deepening, are as old as the borders and the nations themselves. The Scythians traded slaves and wheat with the Greeks. The Hans bartered paper for copper with the Huns. The Silk Route brought tea and gunpowder from China to the Mediterranean. The East India Company had a monopoly charter for an Asian entrepôt even before the Suez Canal conferred on its emporium a locational rent.

Matter has long since gone global. Mind too has broken through the walls. The monks took Buddhism to Sri Lanka and Siam. Magellan took Catholicism to the Philippines. The Romans exported Roman law to the Gauls and the Germans. The Holy Roman Empire mustered an extraterritorial Emperor and a multinational Pope. Secular gospels like nationalism, liberalism and Marxism spread like contagious diseases that travel without documentation. Diaspora peoples like the Chinese, Jamaicans and Indians maintained networks, language and roots that transcended their paper affiliations.

Africans went to the plantations. Chocolate and potatoes came back in return. Globalisation is old. It is not new. What is new is the acceleration of the process and the extent of the penetration. The share of exports added to imports in the world's gross domestic product has increased 
manyfold since the watershed year of 1945. Financial flows and international investment have reached levels undreamt of in the tents of Bedouin nomads or the hill stations of British India. Mass consumption and the information age give the media, the textbooks, the fashions, the lifestyles an international character which is bringing modern citizens of the broadband world ever closer together in what they buy and what they think.

In the age of the open market, as Marx and Engels had predicted, standardisation is the prison from which few have any real desire to escape. The bourgeoisie rules through the economies of scale: 'Its exploitation of the world market has given a cosmopolitan character to production and consumption in every country ... As in material, so also in intellectual production. The intellectual creations of individual nations become common property. National one-sidedness and narrowmindedness become more and more impossible' (Marx and Engels, 1848[2011]: 68-9). National heterogeneity becomes blurred in the face of Westernisation. It is becoming one economy and one way of life. The earth is flat.

Improvements in communication and transportation have facilitated the process. Electronic technology, like printing with movable type in the early Renaissance, has abridged the barriers of time and space. Physical location becomes less important when signals can be transmitted globally in real time. A world market in goods, services, financial assets and human capital is arbitraged into a market-clearing price once microchips diffuse information at a speed that postage stamps can never equal.

Young people are acquiring the general knowledge as well as the sector-specific education they will need to navigate their way through the thicket of computers, smartphones, e-commerce, credit cards, securities markets, ATM machines, online banking, budget airlines, blogs and discussion-boards where English as well as literacy may be essential. The mass media and foreign tourism make points of reference a common possession. On the side of transportation, improvements in refrigeration, cargo aircraft, super-ships, containerisation, deep-sea ports and logistics allow for the long-distance carriage even of perishables. Time and space are being compacted. The process is cumulative.

Technology promotes connectedness. So does the intellectual hard core of free market economics. Ideas like competitive profit-seeking, comparative advantage, rational choice, factor mobility, allocative efficiency have conveyed the message that freedom of enterprise from regulation and nationalisation is the most reliable means to raise living standards. State and plan having been discredited by the switch to devolution in the formerly socialist countries, there would seem to be no alternative. There 
is no popular demand to depart from one-panacea-fits-all because of the idiosyncrasies of a unique national way. Globalisation can be selective. It can be 'accepting triumphant capitalism, American style' (Stiglitz, 2002: 5) rather than scanning the institutional spectrum for a superior standard. Perhaps so; but still it is triumphant capitalism that has survived the institutional sift.

The market paradigm has emerged as a core component of globalisation. It has, however, emerged in tandem with the pragmatic State. Events such as the banking crises of 1997 and 2008 have underscored the need for leadership and governance in areas such as subprime collateral, capital-asset ratios, interest rates, exchange rates, the budget deficit, the international deficit, the balance between consumption and saving, the need to contain currency manipulation and asset bubbles without stifling healthy speculation that promotes a more satisfying use of scarce social resources. At home the State must correct the market failure. The common global perspective is likely to converge on that.

It is also likely to converge on the recommendation that the discrete sovereignties must sometimes work together. Internationally as well as domestically, globalisation and coordination will sometimes require collaborative action in order to get the job done. It has already happened. The classical gold standard after 1880, the Socialist International in 1864, the Congress of Berlin in 1885, the League of Nations in 1920, the Bank for International Settlements in 1930, the British Commonwealth since 1949, the hotline between the Kremlin and White House in 1963, the World Wide Web after 1991 are instances of managed globalisation. So are international and inter-governmental organisations in areas such as security (North Atlantic Treaty Organization, NATO), crime (Interpol), health (World Health Organisation, WHO), heritage (UNESCO) and adjudication (the International Court of Justice). Economics and business are central components in the process of collaboration. The diversity bears witness to the evolution: WTO, IMF, UNCTAD, ASEAN, EU, ECOWAS. State and trade are not perceived to be alternatives. State and trade are believed to be complements. As in the domestic economy, so in the world as a whole. The State has not withered away.

Decisions are made less and less by consumers and producers situated in a single circular flow or nation State. History may be seen as the supersession of politics by the invisible hand. An alternative would, however, be to view the progression not as a move from State to non-State but rather as a move from the nation-State to the cross-border authority. The UN and the EU may be the harbingers of the new world order. Non-local, largely unelected, imperfectly accountable, they alter the meaning of electoral democracy. 
Sovereign democracies are assigned the responsibility for purely domestic issues such as transport, education, citizenship and language. The problem is that purely domestic issues in a super-capitalism sans frontières are no longer hermetically sealed off from the causes and consequences that extend the road-map into foreign territories. Exploitation is outsourced to low-cost countries beyond metropolitan maximum hours and mandatory health insurance. Unemployment and bail-outs become inevitable because distant kingdoms have practised the laissezfaire that they preach. Politics is domestic. The problems that it addresses are not. Without the International Monetary Fund (IMF) and the World Trade Organisation (WTO) it could be the war of each against all again.

Globalisation may transfer authority. Intervention might not be crowded out by homeostasis. Rather, it might be the atoms and the adventurers that fall victim to the new top-down that monitors the cyberspace keystrokes lest money-launderers and drug-smugglers make a virtue of piracy and unstandardised bananas drive a coach and horses through the law of one price. The whole world moved into a Great Depression following the Wall Street crash in 1929. A Great Recession followed the collapse of Lehman Brothers in 2008. If marketisation and commodification have been the free gift of the steamship, the telephone and the telegraph, then so perhaps has a new Leviathan that supernationalises the macroscopic choices on terrorism, Ebola, patents, surrogacy, germ warfare, acid rain, nuclear waste, global warming, immigration controls and human rights. The whales, the tuna and the gibbons are a financial overhead even in countries that have no oceans and jungles.

It can lead to prosperity. It can lead to peace. The older strategies of buffer states and boots in trenches are being marginalised by intercontinental ballistic missiles, spy satellites, drones directed from Montana and multinational forces making war under a single beret. Even the pacifist, anti-global and anti-nuclear movement is supra-national. The earth is flat.

The State is going multinational. It is not going away. In politics as well as economics, the centrifugal and the centripetal are the joint products of the new-style opening-up. It is all a question of multiple identities and nested allegiances. Yet a historical pit-stop should not be mistaken for a natural law. Nothing is irreversible. Nineteenth-century free trade was swallowed up by inter-war beggar-thy-neighbour. The optimism of Bretton Woods soon collapsed into floating exchange rates and IMF conditionality. The EU has come under attack from member nations who believe that fiscal policy must remain a domestic concern and from outsiders who maintain that common agricultural protection is a tax on the impoverished Third World. There are new sources of tension 
when cultures collide. New identities emerge that are not rooted in territory. Gender, race, age-cohort and religion can become divisive. Unrestricted immigration can produce mass xenophobia. The Scots, believing that the international idea can go too far, might identify themselves as Scots and not simply as comparative advantage. Nothing is inevitable. The Romans thought their imperium and their pax would last forever. Sic transit gloria mundi. Where are they now?

Nothing is set in stone. A kaleidoscope is not built in a day. This book narrows its horizons to the real, existing real world. The position is clear. For today at least, what is is State and trade. The State is "who gets what, when, and how': 'The study of politics is the study of influence and the influential' (Lasswell, 1958[1936]: 13). Trade is exchange: 'Give me that which I want, and you shall have this which you want' (Smith, 1961[1776]: I, 18). This book is concerned with the world mixed economy. It is concerned with the double duality of the individual and the collective, national decision-making and transnational authority. Matter is in motion and the future is a terra incognita. This book constructs a road-map through the double duality of a mixed economy that is recalcitrant to eternal truths, set in stone. 